\title{
Antioxidant Properties and Characterization of Heterotrigona itama Honey from Various Botanical Origins according to Their Polyphenol Compounds
}

\author{
Sharina Shamsudin $\left(\mathbb{D},{ }^{1,2}\right.$ Jinap Selamat $\mathbb{D}^{1,3}$ Mukramah Abdul Shomad ${ }^{1 D},{ }^{1}$ \\ Muhamad Faris Ab Aziz $\mathbb{D}^{4},{ }^{4}$ and Md. Jahurul Haque Akanda $\mathbb{D D}^{5}$ \\ ${ }^{1}$ Faculty of Food Science and Technology, Universiti Putra Malaysia, 43400 Serdang, Selangor, Malaysia \\ ${ }^{2}$ Science and Food Technology Research Centre, Malaysian Agricultural Research and Development Institute, \\ Persiaran MARDI-UPM, 43400 Serdang, Selangor, Malaysia \\ ${ }^{3}$ Food Safety and Food Integrity Institute of Tropical Agriculture and Food Security, Universiti Putra Malaysia, 43400 Serdang, \\ Selangor, Malaysia \\ ${ }^{4}$ Department of Animal Science, Faculty of Agriculture, Universiti Putra Malaysia, 43400 Serdang, Selangor, Malaysia \\ ${ }^{5}$ Department of Agriculture, School of Agriculture, University of Arkansas, 1200 North University Dr. M/S 4913, Pine Bluff, \\ AR 71601, USA
}

Correspondence should be addressed to Jinap Selamat; sjinap@gmail.com

Received 26 August 2021; Revised 10 December 2021; Accepted 5 January 2022; Published 25 February 2022

Academic Editor: Yuxia Fan

Copyright (C) 2022 Sharina Shamsudin et al. This is an open access article distributed under the Creative Commons Attribution License, which permits unrestricted use, distribution, and reproduction in any medium, provided the original work is properly cited.

\begin{abstract}
Stingless bee honey is a good source of antioxidants, which is attributed to the phenolic compounds. The type and concentration of phenolic compounds in honey can be affected by botanical origin. Therefore, in this study, Heterotrigona itama honey from three botanical origins (gelam, acacia, and starfruit) was evaluated for its antioxidant activity and profile of phenolic compounds. Apis mellifera honey was used as a comparison. Antioxidant activity and profile of phenolic compounds in honey were determined using spectrophotometric and chromatographic methods, respectively. The total phenolic content (TPC), total flavonoids content (TFC), free radical scavenging activity $\left(\mathrm{IC}_{50}\right)$, and ferric reducing antioxidant power (FRAP) of $H$. itama were ranged between 52.64 and $74.72 \mathrm{mg} \mathrm{GAE} / 100 \mathrm{~g}$ honey, $10.70-25.71 \mathrm{mg}$ QE/100 g honey, $11.27-24.09 \mathrm{mg} / \mathrm{mL}$, and 77.88-164.88 $\mu \mathrm{mol} \mathrm{FeSO}_{4} .7 \mathrm{H}_{2} \mathrm{O} / 100 \mathrm{~g}$ honey, respectively. The findings showed that the antioxidant activity and phenolic and flavonoid contents in $H$. itama honey were significantly higher than Apis honey. Benzoic acid and taxifolin were found as the predominant phenolic acid and flavonoid in all samples. However, chrysin was significantly highest in Apis honey than stingless bee honey. This result suggested that chrysin can be used as a chemical marker to distinguish Apis honey from stingless bee honey. Gallic acid and ellagic acid were found as the chemical marker for gelam honey, salicylic acid, benzoic acid, and 4-hydroxybenzoic acid for starfruit honey while ferulic acid for acacia honey.
\end{abstract}

\section{Introduction}

Honey is produced by stingless bees and honeybees mainly from the nectar of plants or plant sap [1]. It has been documented that honey is a complex substance and contains over 200 components, which may be either produced during the maturation process of honey, added by bees, or derived from plants [2]. The main components of honey are sugar and water. It also comprises important minor components such as organic acids, amino acids, vitamins, minerals, enzymes, and phenolic compounds. The composition of honey and phenolic compounds primarily depends on the botanical origin $[3,4]$ and external factors such as harvesting season, environment, storage, and processing method. Phenolic compounds are the most important antioxidant in honey that are responsible for the honey's therapeutic properties. Thus, honey has been used in traditional and modern treatments to treat human illnesses. In modern 
treatment, honey has been used to treat diseases associated with oxidative stress such as diabetes mellitus, hypertension, atherosclerosis, cancer, and Alzheimer's [5]. In addition, phenolic compounds also can affect the organoleptic properties (color, taste, or flavor) of honey [2]. In a recent study, phenolic compounds have been used as a chemical marker to differentiate honey from different botanical and geographical origins [6]. For instance, abscisic acid was reported as a potential floral marker for two Polish unifloral honey [7], and quercetin was suggested as a marker for sunflower honey [8].

Phenolic compounds (phenolic acids and flavonoids) are the secondary components of plants [9] that transfer to honey through nectar, pollen, or propolis by bees [10]. They are responsible for the most antioxidant activity in honey [11]. In recent years, there has been a growing interest in identifying phenolic compounds in stingless bee honey as it has been reported to have higher antioxidant activity and is considered as a potential source of antioxidants compared to Apis mellifera honey, which is good for human health and well-being [12]. Biluca et al. [13], da Silva et al. [14], Sousa et al. [15], and Olivera et al. [16] have identified numerous phenolic compounds in Melipona and Trigona honey. All the studies are from America Latin. However, in Malaysia, there is very limited scientific data on the profile of phenolic compounds in stingless bee honey. Ranneh et al. [17] investigated Malaysian stingless bee honey and Tualang honey. They found gallic, caffeic, syringic, catechin, cinnamic, p-coumaric, apigenin, and 4-hydroxybenzoic as major compounds. Recently, Majid et al. [18] reported six phenolic compounds (chlorogenic acid, p-coumeric acid, epicatechin, rutin, catechin, and protocatechuic acid in unifloral and multifloral honey produced by Heterotrigona itama from Johor. Moreover, there are no available studies on phenolic compounds in stingless bee honey from acacia, gelam, and starfruit. Therefore, more studies need to be conducted to explore and identify more phenolic acids and flavonoids present in stingless bee honey from different botanical origins. In this study, three types of stingless bee honey (acacia, gelam, and starfruit) that are commonly consumed in Malaysia were investigated. The main goal of this present study was to determine the phenolic profiles of stingless bee honey and Apis honey by identifying their phenolic acids and flavonoids, correlate antioxidant activity with phenolic compounds, and verify the botanical origin according to the specific phenolic compounds using multivariate statistical method.

\section{Materials and Methods}

2.1. Materials. Methanol $(\mathrm{MeOH})$, hydrochloric acid $(\mathrm{HCl})$, formic acid $\left(\mathrm{CH}_{2} \mathrm{O}_{2}\right)$, acetic acid $\left(\mathrm{CH}_{3} \mathrm{COOH}\right)$, sodium acetate $\left(\mathrm{CH}_{3} \mathrm{COONa}\right)$, sodium Carbonate $\left(\mathrm{NaCO}_{3}\right)$, sodium nitrite $\left(\mathrm{NaNO}_{2}\right)$, aluminum chloride $\left(\mathrm{AlCl}_{3}\right)$, sodium hydroxide $(\mathrm{NaOH})$, ferric tripyridyltriazine $\left(\mathrm{Fe}^{3+}-\mathrm{TPTZ}\right)$, iron (III) chloride hexahydrate, 2,2-diphenyl-1-picrylhydrazyl (DPPH) radicals, Folin-Ciocalteu reagent, and amberlite XAD-2 resin were purchased from Fisher Scientific (Pittsburg, PA). Phenolic compound standards (gallic acid, 3, 4-

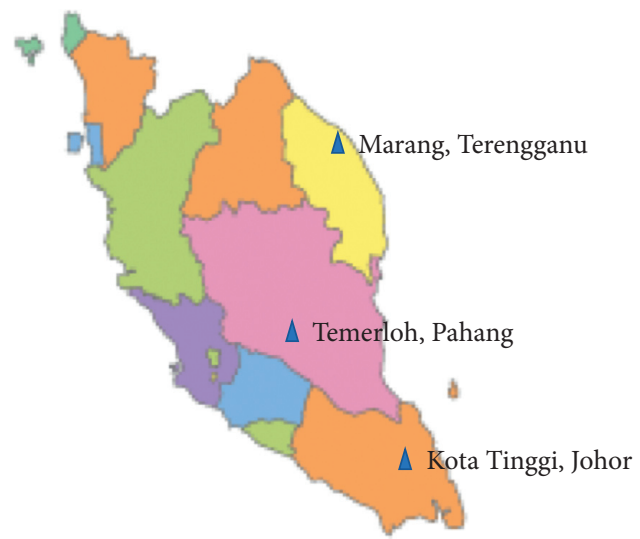

Figure 1: Source of honey.

dihydroxybenzoic acid, 4-hydroxybenzoic acid, chlorogenic acid, syringic acid, (-)-epicatechin, (+-)-catechin hydrate, p-coumaric acid, ferulic acid, ellagic acid, benzoic acid, salicylic acid, trans-cinnamic acid, vanillic acid, caffeic acid, taxifolin, myricetin, quercetin hydrate, (+-)-naringenin, and chrysin) were obtained from Sigma Chemical Co. (St. Louis, $\mathrm{MO})$. For HPLC analysis, all chemicals and solvents were of HPLC grade.

2.2. Honey Samples. Natural stingless bee honey produced by $H$. itama from acacia (Acacia mangium), starfruit (Averrhoa carambola L.), and gelam (Meleleuca cajaputi Powell) were obtained from three different farms that cultivated acacia, gelam, and starfruit trees located in Johor, Terengganu, and Pahang, respectively (Figure 1). The samples were collected during the flowering season between August and November 2016. A. mellifera honey (acacia) was used as a comparison in this study. The botanical origin of the honey samples was determined based on the location of beehives and the availability of the floral source on the farm. The samples were collected using a vacuum pump and filtered to remove foreign materials. They were stored in airtight containers and kept at $4^{\circ} \mathrm{C}$ until further analysis. The details of honey samples used are summarized in Table 1.

2.3. Total Phenolic Content. The total phenolic content (TPC) was determined using Folin-Ciocalteu assay according to the method described by Garjanovic et al. [19] with some modifications. A $200 \mu \mathrm{L}$ of honey solution $(0.05 \mathrm{~g} /$ $\mathrm{mL}$ methanol) was added to $1 \mathrm{~mL}$ of Folin-Ciocalteu reagent in a test tube. Then, the mixture was allowed to stand at room temperature. After $6 \mathrm{~min}, 800 \mu \mathrm{L}$ of sodium carbonate solution $\left(7.5 \% \mathrm{Na}_{2} \mathrm{CO}_{3}\right)$ was added to the mixture. Then, the mixture was left to stand for $2 \mathrm{~h}$ in a dark room at room temperature. The absorbance of the mixture was measured at $740 \mathrm{~nm}$ using a UV-visible spectrophotometer (GENESYS ${ }^{\mathrm{TM}}$ 10S, Thermo Fisher Scientific, MA). The calibration curve was prepared using gallic acid at concentrations between 10 and $50 \mu \mathrm{g} / \mathrm{mL}\left(r^{2}=0.9999\right)$. Results were expressed as $\mathrm{mg}$ gallic acid equivalents (GAE) per $100 \mathrm{~g}$. The analysis was performed in triplicate. 
TABLE 1: Botanical origin of the honey samples used in this study.

\begin{tabular}{lccc}
\hline Bee species & Type of honey (common name) & Botanical origin (scientific name) & Location \\
\hline & Acacia & Acacia mangium & Johor \\
Heterotrigona itama & Gelam & Meleleuca cajaputi Powell & Terengganu \\
& Starfruit & Averrhoa carambola L. & Pahang \\
\hline Apis mellifera (as a comparison) & Acacia & Acacia mangium & Johor \\
\hline
\end{tabular}

2.4. Total Flavonoids Content. The total flavonoid content (TFC) was measured according to the method suggested by Kamboj et al. [20] with minor modifications. One milliliter of honey solution $(0.25 \mathrm{~g} / \mathrm{mL}$ methanol) was mixed with $0.3 \mathrm{~mL}$ of $5 \%$ sodium nitrite $\left(\mathrm{NaNO}_{2}\right)$. The mixture was left to stand for $5 \mathrm{~min}$ at room temperature. Afterward, $0.3 \mathrm{~mL}$ of $10 \%$ aluminum chloride $\left(\mathrm{Al}_{3} \mathrm{Cl}\right)$ was added, and the mixture was allowed to stand at room temperature for $6 \mathrm{~min}$. Finally, $2 \mathrm{~mL}$ of $1 \mathrm{M}$ of sodium hydroxide $(\mathrm{NaOH})$ was added to the mixture. The absorbance of the mixture was measured at $510 \mathrm{~nm}$ using a UV-visible spectrophotometer (GENESYS ${ }^{\text {тм }}$ 10S, Thermo Fisher Scientific, MA). Quercetin was used as a standard to plot the calibration curve at the concentrations of $10-50 \mu \mathrm{g} / \mathrm{mL}\left(r^{2}=0.98\right)$. The results were expressed as $\mathrm{mg}$ quercetin equivalent $(\mathrm{QE})$ per $100 \mathrm{~g}$. The analysis was carried out in triplicate.

2.5. Free Radical Scavenging Activity. The scavenging activities of the honey samples were measured by DPPH assay as described by Meda et al. [21] with slight modifications. A $400 \mathrm{mg}$ of honey sample was mixed with different amounts of methanol $(3,6,9,12$, and $15 \mathrm{~mL})$ separately. Then, $0.75 \mathrm{~mL}$ of honey in methanol was mixed with $1.5 \mathrm{~mL}$ of $\mathrm{DPPH}$ solution. The mixture was left in the dark area for $15 \mathrm{~min}$ at room temperature. The absorbance was measured against a blank solution containing water with a UV-visible spectrophotometer (A GENESYS ${ }^{\text {TM }}$ 10S, Thermo Fisher Scientific, MA) at $517 \mathrm{~nm}$. The antiradical activity of the sample was calculated using the following formula:

$$
\text { antiradical activity }(\%)=\left[\frac{\left(A_{c}-A_{s}\right)}{A_{c}}\right] \times 100 \%,
$$

where $A_{c}$ is the absorbance of the control and $A_{s}$ is the absorbance of the sample. Each honey sample was analyzed in five dilutions. The antiradical activity was expressed as $\mathrm{IC}_{50}$ (the concentration of honey solution needed to reduce the concentration of DPPH in the solution to $50 \%$ of its initial concentration). The concentration of honey sample required to scavenge $50 \%$ of $\mathrm{DPPH}\left(\mathrm{IC}_{50}\right)$ was determined from the plotted graph of scavenging activity against the honey dilutions.

2.6. Ferric Reducing Antioxidant Power. The reducing ability of the sample was carried out according to the procedure described by Khalil et al. [22] with slight modifications. The method was based on the reduction of $\mathrm{Fe}^{3+}-\mathrm{TPTZ}$ to a bluecolored $\mathrm{Fe}^{2+}$ FRAP reagent. It was prepared by mixing $0.3 \mathrm{M}$ of acetate buffer ( $\mathrm{pH} 3.6), 10 \mathrm{mM}$ of TPTZ, and $20 \mathrm{mM}$ $\mathrm{FeCl}_{3} \cdot 6 \mathrm{H}_{2} \mathrm{O}$ in a ratio of $10: 1: 1$ at $37^{\circ} \mathrm{C}$. A $200 \mu \mathrm{L}$ of the honey sample $(0.05 \mathrm{~g} / \mathrm{mL})$ in methanol was added to $1.5 \mathrm{~mL}$ of FRAP reagent in a test tube. After $10 \mathrm{~min}$ of incubation at $37^{\circ} \mathrm{C}$ in a water bath, the absorbance was measured using the UV-visible spectrophotometer (GENESYS ${ }^{\mathrm{Tm}} 10 \mathrm{~S}$, Thermo Fisher Scientific, MA) at $593 \mathrm{~nm}$. The antioxidant potential of the sample was determined from a standard curve using ferrous sulfate heptahydrate $\mathrm{FeSO}_{4} .7 \mathrm{H}_{2} \mathrm{O}$ at concentrations between 10 and $100 \mu \mathrm{g} / \mathrm{mL}\left(r^{2}=0.98\right)$. Triplication of the test was performed, and the results were expressed as the mean average.

\subsection{Extraction of Phenolic Compounds Using XAD-2 Resin.}

The extraction of phenolic compounds was prepared according to the method described by Kassim et al. [23] and Ferreira et al. [24] with some modifications. A $10 \mathrm{~g}$ of honey sample was mixed with $100 \mathrm{~mL}$ of acidified water $(\mathrm{pH} \mathrm{2}$; $0.02 \mathrm{M} \mathrm{HCl}$ ) and $150 \mathrm{~g}$ of Amberlite XAD-2 resin (Fluka Chemei; pore size $=9 \mathrm{~nm}$; particle size $=0.3-1.2 \mathrm{~mm}$ ). The mixture was then homogenized for $10 \mathrm{~min}$. The mixture was poured into a column $(35 \times 2 \mathrm{~cm})$ and washed with $100 \mathrm{~mL}$ of acid solution $(0.02 \mathrm{M} \mathrm{HCl})$ to remove all sugars and other polar constituents in honey. Subsequently, $300 \mathrm{~mL}$ of deionized water was used to rinse the mixture in the column. The phenolic fractions were eluted with $100 \mathrm{~mL}$ of methanol and evaporated using a rotary evaporator until dry at $40^{\circ} \mathrm{C}$. Methanol was used based on its ability to extract more phenolic compounds as reported by Kassim et al. [23]. The residues were dissolved in $250 \mu \mathrm{L}$ methanol for HPLC analysis.

2.8. HPLC Analysis. The detection of phenolic compounds was performed using high-performance liquid chromatography equipped with a diode array detector (HPLC-DAD). The column used was a reversed-phase C18 column, ACE $(4.6 \times 250 \mathrm{~mm}$, particle size $5 \mu \mathrm{M})$ from Altmann Analytik $\mathrm{GmbH} \&$ Co. KG (Munich, Germany). Approximately $10 \mu \mathrm{L}$ of the phenolic extract was injected into the HPLC, and the separation was performed using $0.25 \%$ formic acid and $2 \%$ methanol in water (solvent A) and methanol (solvent B). The gradients used were: $10 \%$ methanol (B) for $15 \mathrm{~min}, 40 \%$ methanol (B) for $20 \mathrm{~min}, 45 \%$ methanol (B) for $30 \mathrm{~min}, 60 \%$ methanol (B) for $50 \mathrm{~min}, 80 \%$ methanol (B) for $52 \mathrm{~min}, 90 \%$ methanol (B) for $60 \mathrm{~min}$, and followed by isocratic elution with $90 \%$ methanol (B) for $65 \mathrm{~min}$. Then, the gradient was changed to $10 \%$ methanol for $68 \mathrm{~min}$ until $73 \mathrm{~min}$. The flow rate used was $1 \mathrm{~mL} / \mathrm{min}$. Phenolic compounds were detected using UV absorption spectra monitored at $290 \mathrm{~nm}$ and $340 \mathrm{~nm}$. The phenolic compounds were identified by comparing the chromatographic retention times with the 
standards. The calibration curve of the standards was used to determine the concentration of the phenolic compounds in the extracts [23].

2.9. Statistical Analysis. All analyses were conducted in triplicate, and the data were expressed as means \pm standard deviation. Analysis of variance (ANOVA) and Turkey's test at the $95 \%$ confidence level were performed using MINITAB software (State College, PA). Correlations between antioxidant activity and TPC, TFC, $\mathrm{IC}_{50}$, and FRAP were obtained by Pearson's correlation analysis. Multivariate analysis was performed using MINITAB software (State College, PA).

\section{Results and Discussion}

\subsection{Antioxidant Properties of Honey}

3.1.1. Total Phenolic Content and Total Flavonoids Content. The antioxidant capacity of honey is usually measured by evaluating the contents of phenolic and flavonoids as they are the key compounds responsible for the antioxidant activity of honey [13]. TPC values in the honey samples ranged between 52.64 and $74.62 \mathrm{mg}$ GAE/100 $\mathrm{g}$ honey (Table 2). A significant difference $(p<0.05)$ was observed in TPC values between $H$. itama (gelam and starfruit honey) and $A$. mellifera honey. Gelam honey showed the significantly highest value of TPC, while acacia honey obtained the lowest value. However, no significant differences $(p>0.05)$ were observed among $H$. itama honey from different botanical origins. In contrast, Abu Bakar et al. [25] demonstrated the TPC value of $H$. itama from Malaysia was higher than our results. The TPC values varied between 435.69 and $516.07 \mathrm{mg}$ GAE/100 g honey. Recently, Imtiazah et al. [26] reported $368.11 \mathrm{mg}$ GAE/100 g honey total phenolic content. However, Tufail Ahmad et al. [27] reported $5.86 \mathrm{mg}$ GAE/ $100 \mathrm{~g}$ honey total phenolic content in Malaysian stingless bee honey produced by Geniotrigona thoracica, which was lower than our results. Ranneh et al. [17] also reported lower TPC in stingless bee honey collected from the forest in Kedah and Johor. The values varied between 228.09 and $235.28 \mathrm{mg}$ GAE/kg honey. Ismail et al. [28] reported 33.2-60.2 mg GAE/100 g honey of total phenolic content, which agreed with our study. In comparison to other countries, the results found in this study were comparable to those found by Silva et al. [29] and da Silva et al. [14], where the TPC values were ranged between 1.30 and $66 \mathrm{mg}$ GAE/100 $\mathrm{g}$ honey for stingless bee honey from Paraiba and Amazona, Brazil. Furthermore, Silva et al. [29] also reported the higher TPC values in nine Melipona subnitida honey from two semiarid regions, Paraiba, Brazil.

The TFC values of $H$. itama honey and Apis honey are shown in Table 2 . The highest TFC value (25.71 mg QE/100 g honey) was found in starfruit honey, followed by gelam (20.67 mg QE/100g honey), acacia (10.70 mg QE/100 g honey), and Apis (7.02 mg QE/100 g honey) honey. A significant difference $(p<0.05)$ was observed in all honey samples investigated. In comparison with Malaysian stingless bee honey, Ranneh et al. [17] and Selvaraju et al. [30] reported lower TFC where the values ranged between
97.88 and $101.5 \mathrm{mg} \mathrm{CE} / \mathrm{kg}$ and 10.18 and $12.68 \mathrm{mg} \mathrm{CE} / \mathrm{kg}$, respectively. In a recent study, Imtiazah et al. [26] also demonstrated a lower TFC in Malaysian stingless bee honey (64.25 mg CEQ/kg honey). However, higher TFC was found in multifloral stingless bee honey collected in Sabah and Kelantan with values between 43.2 and $65.9 \mathrm{mg}$ QE/100 g honey [28]. The results from this study were consistent with those reported for stingless bee honey from Alagoas, Brazil, 11.69-49.50 mg QE/100 g honey [31]. Nevertheless, a higher TFC value was found in six species of Melipona honey from Brazil [32] and a lower TFC value in Melipona beecheii honey from Cuba [11].

Overall, stingless bee honey had significantly higher TPC and TFC as compared to Apis honey. A low concentration of phenolic acids and flavonoids may contribute to the low TPC and TFC values of Apis honey as shown in Table 3. In addition to that, the difference can be explained by the different bee species and the way honey is produced by two different bees [33]. While the variation observed between stingless bee honey is due to the different botanical origins of the honey as the botanical origin has a direct association with the phenolic compounds present in honey [34]. Comparison of TPC and TFC data with similar honey from Malaysia and other regions could not be done as there is no related publication available.

3.1.2. The Free Radical Scavenging Activity and Ferric Reducing Antioxidant Power. Antioxidant activities of honey samples were estimated using 2,2-diphenyl-1-picrylhydrazyl (DPPH) and ferric reducing antioxidant power (FRAP) assays. The free radical scavenging activity of honey samples was expressed as $\mathrm{IC}_{50}$, indicating the amount of antioxidant needed to reduce the initial concentration of DPPH solution by $50 \%$. Honey with a low value of $\mathrm{IC}_{50}$ has greater antioxidant activity than honey with a high value of $\mathrm{IC}_{50}$ [35]. Results of the free radical scavenging activity of honey samples are presented in Table 2. The $\mathrm{IC}_{50}$ value of $H$. itama honey varied between 11.27 and $24.09 \mathrm{mg} / \mathrm{mL}$ with the gelam honey having the lowest value. Thus, gelam honey had greater antioxidant activity than starfruit and acacia honey, but no significant difference $(p>0.05)$ was observed among them. Aljadi and Kamaruddin [36] also reported that gelam honey (honeybee honey) had higher antioxidant activity than coconut honey. Kek et al. [37] reported $26.63 \mathrm{~mL} / \mathrm{g}$ in Malaysian stingless bee honey produced by H. itama. While Ismail et al. [28] reported a range of $10.6-19.7 \mathrm{mg} / \mathrm{mL}$, which was consistent with our results. When compared to the stingless bee honey from Brazil, the $\mathrm{IC}_{50}$ value in this study was lower than the results reported $(25.39-51.55 \mathrm{mg} / \mathrm{mL})$. While the $\mathrm{IC}_{50}$ value of $H$. itama honey $(11.27-24.09 \mathrm{mg} /$ $\mathrm{mL}$ ) was lower than Apis honey $(53.65 \mathrm{mg} / \mathrm{mL})$. A similar finding was reported by Duarte et al. [31]. However, there was no significant difference found among the honey samples except between gelam and Apis honey. In contrast, Alvarez-Suarez et al. [12] reported a higher $\mathrm{IC}_{50}$ in M. beecheii honey than Apis honey.

The ferric reducing antioxidant power (FRAP) analysis was performed to measure the ability of phenolic 
TABLE 2: The antioxidant properties (total phenolic content, total flavonoid content, DPPH $\mathrm{IC}_{50}$, and FRAP) of Heterotrigona itama and Apis mellifera honey.

\begin{tabular}{|c|c|c|c|c|}
\hline \multirow{2}{*}{ Parameters } & \multicolumn{3}{|c|}{ Heterotrigona itama } & \multirow{2}{*}{$\begin{array}{c}\text { Apis mellifera } \\
\text { Acacia }\end{array}$} \\
\hline & Acacia & Gelam & Starfruit & \\
\hline Total phenolic content (mg GAE/100 g honey) & $58.39 \pm 4.14^{\mathrm{ab}}$ & $74.72 \pm 6.88^{\mathrm{a}}$ & $70.83 \pm 1.03^{\mathrm{a}}$ & $52.64 \pm 2.45^{\mathrm{b}}$ \\
\hline Total flavonoid content (mg QE/100 g honey) & $10.70 \pm 0.71^{\mathrm{c}}$ & $20.67 \pm 0.23^{\mathrm{b}}$ & $25.71 \pm 0.08^{\mathrm{a}}$ & $7.02 \pm 0.06^{\mathrm{d}}$ \\
\hline $\mathrm{DPPH}\left(\mathrm{IC}_{50}\right)(\mathrm{mg} / \mathrm{mL})$ & $21.41 \pm 3.80^{\mathrm{ab}}$ & $11.27 \pm 2.40^{\mathrm{b}}$ & $24.09 \pm 1.77^{\mathrm{ab}}$ & $53.65 \pm 2.55^{\mathrm{a}}$ \\
\hline FRAP $\left(\mu \mathrm{mol} \mathrm{FeSO}_{4} \cdot 7 \mathrm{H}_{2} \mathrm{O} / 100 \mathrm{~g}\right.$ honey $)$ & $77.8 \pm 2.39^{\mathrm{b}}$ & $141.68 \pm 4.94^{\mathrm{a}}$ & $164.88 \pm 11.79^{\mathrm{a}}$ & $72.78 \pm 1.45^{\mathrm{b}}$ \\
\hline
\end{tabular}

${ }^{*}$ Data are expressed as mean \pm standard deviation (SD). The small letters in the same raw (a-d) indicate significant differences at the level of $p<0.05$ between honey samples from different botanical origins. $\mathrm{GAE}=$ gallic acid equivalent, $\mathrm{QE}=$ quercetin equivalent, and $\mathrm{DPPH}\left(\mathrm{IC}_{50}\right)=$ free radical scavenging activity.

TABLE 3: Correlation matrix between total phenolic content (TPC) and total flavonoids content (TFC) and antioxidant activity (FRAP and $\left.\mathrm{DPPH}\left(\mathrm{IC}_{50}\right)\right)$ of Heterotrigona itama and Apis honey.

\begin{tabular}{lcccc}
\hline Variables & TPC & TFC & DPPH $\left(\mathrm{IC}_{50}\right)$ & FRAP \\
\hline TPC & 1.000 & & & \\
TFC & $0.922^{* *}$ & 1.000 & & \\
DPPH $\left(\mathrm{IC}_{50}\right)$ & $-0.813^{* *}$ & $-0.658^{* *}$ & 1.000 & \\
FRAP & $0.919^{* *}$ & $0.991^{*}$ & $-0.588^{* *}$ & 1.000 \\
\hline
\end{tabular}

${ }^{*}$ Significant at $p<0.05 ;{ }^{* *}$ Not significant at $p<0.05$. TPC $=$ total phenolic content, $\mathrm{TFC}=$ total flavonoids content, $\mathrm{DPPH}=$ free radical scavenging activity, and FRAP $=$ ferric reducing antioxidant power.

compounds as an antioxidant to reduce ferric ions $\left(\mathrm{Fe}^{3+}\right)$ to ferrous ions $\left(\mathrm{Fe}^{2+}\right)$. From the results in Table 2, the FRAP values of all honey samples varied between 72.78 and $164.88 \mu \mathrm{mol} \mathrm{FeSO} 4.7 \mathrm{H}_{2} \mathrm{O} / 100 \mathrm{~g}$ honey, where both gelam and starfruit honey displayed significantly $(p<0.05)$ higher FRAP values than those from acacia and Apis honey. Among the analyzed honey samples, starfruit honey showed the highest FRAP value, which indicated that starfruit honey possesses a stronger reducing power than other honey samples. The values of FRAP in this study were higher than those reported by Alvarez-Suarez et al. [12] on Cuban honey (M. beecheii) of $38.54 \mu \mathrm{mol} \mathrm{FeSO} 4.7 \mathrm{H}_{2} \mathrm{O} / 100 \mathrm{~g}$ honey but lower than those reported by Chan et al. [38] on Malaysia honey (Trigona spp.) of 3,630.18-7,477.03 $\mu \mathrm{mol}$ FeS$\mathrm{O} 4.7 \mathrm{H}_{2} \mathrm{O} / \mathrm{kg}$ honey and by Nweze et al. [39] on Nigerian honey of $417.36-439.15 \mu$ mol $\mathrm{FeSO} 4.7 \mathrm{H}_{2} \mathrm{O} / 100 \mathrm{~g}$ honey. In recent studies, Majid et al. [23] and Tufail Ahmad et al. [27] reported higher FRAP values of Malaysian stingless bee honey ranging between 283.80 and $1401.80 \mu \mathrm{M} \mathrm{Fe}$ (II)/100 g honey and $27.18 \mu \mathrm{mol} \mathrm{FeSO} 4.7 \mathrm{H}_{2} \mathrm{O} / \mathrm{g}$ honey, respectively.

The variation in $\mathrm{IC}_{50}$ and FRAP values in the honey samples analyzed could attribute to the different amounts and types of phenolic compounds [40] presented in the honey samples as the samples used in this study belonged to different botanical origins. Therefore, honey from different botanical origins possesses distinct antioxidant activity [14].

3.2. Correlation Analysis. The Pearson's correlation showed a significant correlation between FRAP and TFC (0.991). This indicates that flavonoids are the greatest contributor to the reducing power of honey. Nevertheless, no significant correlation was observed between TPC and TFC (0.922), between DPPH $\left(\mathrm{IC}_{50}\right)$ and TPC $(-0.813)$ and TFC $(-0.658)$, and between FRAP and TPC (0.919) and DPPH $\left(\mathrm{IC}_{50}\right)$
$(-0.588)$. The findings from this study also suggest that the antioxidant activity of honey is not only influenced by the phenolic and flavonoids content but also other antioxidant compounds that partially contribute to the antioxidant activity of honey. As known, honey contains a wide variety of significant antioxidant compounds such as organic acids, amino acids, enzymes, carotenoids, Maillard reaction products, and proteins [34, 41, 42]. Duarte et al. [30] also reported a significant correlation between the FRAP and flavonoids content in Africanized and stingless bee honey from Alagoas, Brazil. Other studies also demonstrated a significant correlation between the FRAP and flavonoids content, suggesting flavonoids as one of the key components responsible for the antioxidant activity of honey $[22,40,43,44]$.

3.3. Limit of Detection and Limit of Quantitation of Phenolic Compounds. The limit of detection (LOD) and limit of quantitation (LOQ) values were calculated based on the $3 *$ standard deviation of blank response/slope and $10 *$ standard deviation of blank response/slope, respectively. The LOD of phenolic acids and flavonoids were ranged between 0.30 and $148.33 \mu \mathrm{g} / 100 \mathrm{~g}$ honey and $0.05-0.55 \mu \mathrm{g} / 100 \mathrm{~g}$ honey, respectively, while the LOQ of phenolic acids and flavonoids were ranged between 1.25 and $494.38 \mu \mathrm{g} / 100 \mathrm{~g}$ honey and $0.18-1.85 \mu \mathrm{g} / 100 \mathrm{~g}$ honey, respectively.

3.4. Phenolic Profile. Phenolic compounds identification was performed using HPLC analysis. The chromatograms of the standard of phenolic compounds and honey samples are shown in Figures 2(a) and 2(b), respectively. Table 4 shows the phenolic compounds present in all honey samples. Sixteen compounds were found in starfruit honey, while 15 compounds were identified in acacia and gelam honey. These results indicate that all honey samples possess almost similar phenolic compound profiles; however, different concentrations were quantified in the honey sample from different botanical origins. Ranneh et al. [17] found 13 phenolic compounds (gallic acid, caffeic acid, caffeic acid phenethyl ester, syringic acid, catechin, apigenin, chrysin, cinnamic acid, 2-hydroxybenzoic acid, kaempferol, p-coumaric acid, quercetin-3-O-rutinosid, and 4-hydroxybenzoic acid) in Malaysian stingless bee honey using LC-ESI-MS/ MS. On the contrary, Majid et al. [18] identified 6 phenolic compounds (chlorogenic acid, p-coumaric acid, catechin, 

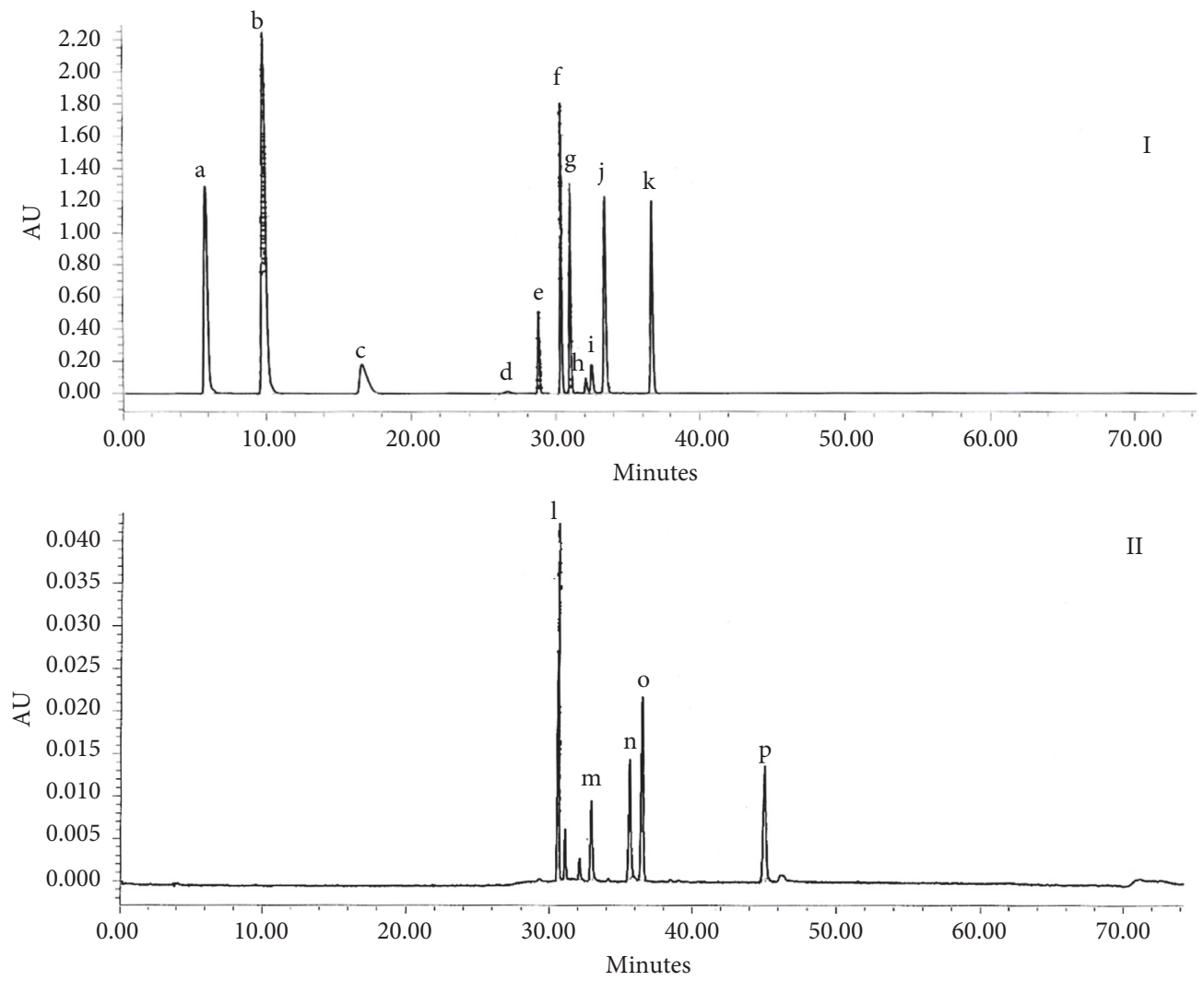

(a) 

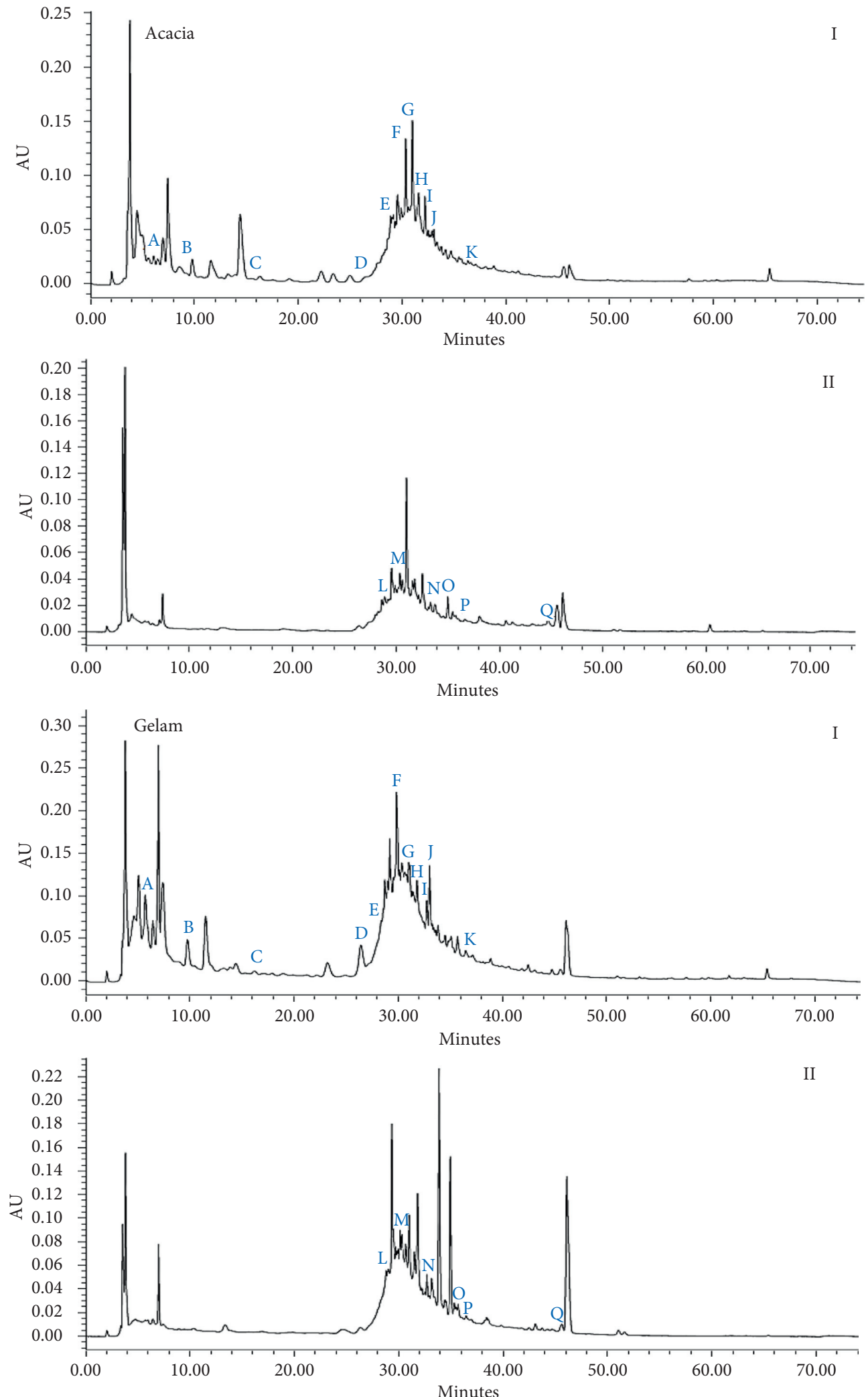

(b) 

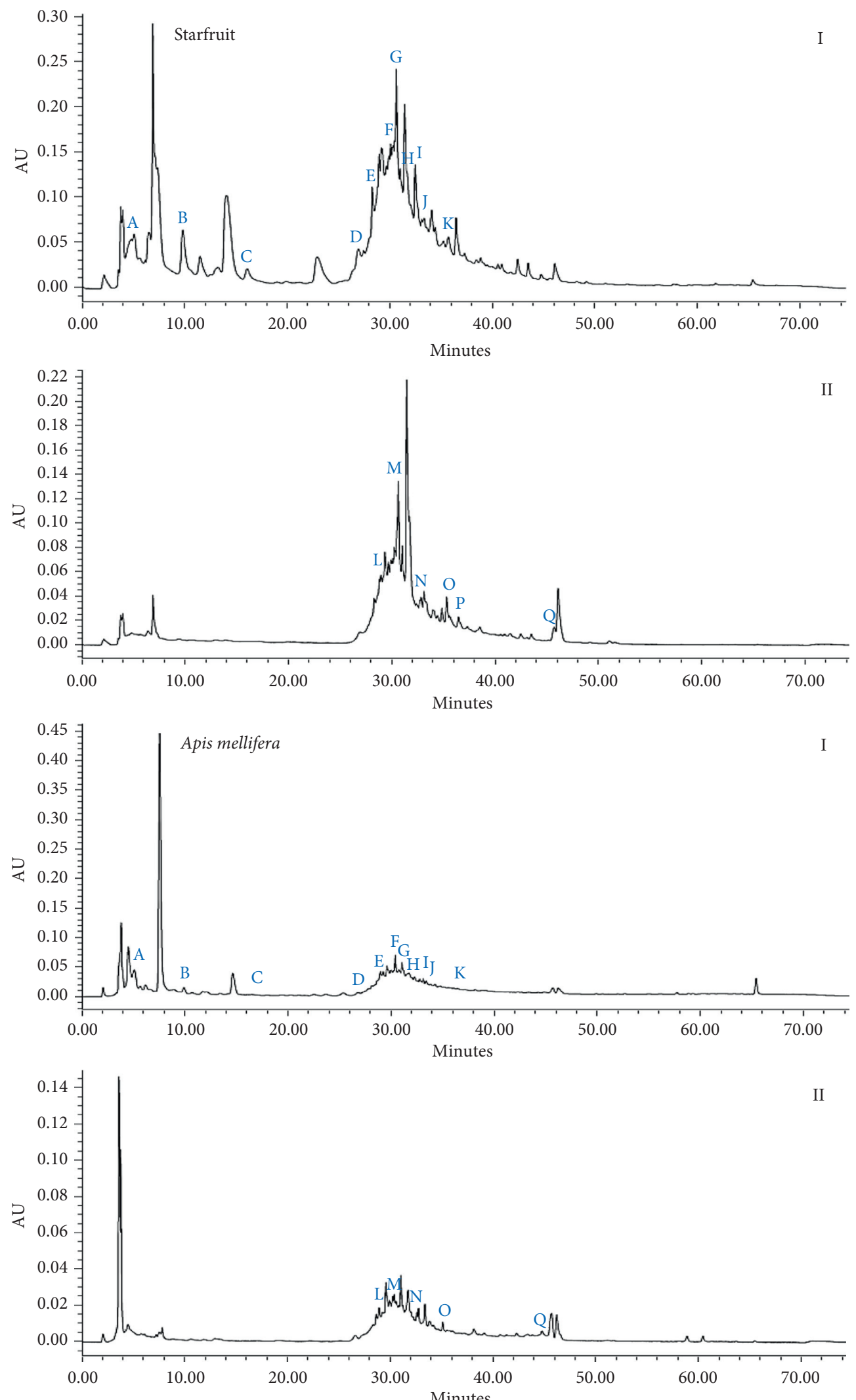

(c)

FIGURE 2: Chromatogram of standard of phenolic compounds (a) and chromatogram of phenolic acids and flavonoids detected in Heterotrigona itama (acacia, gelam, and starfruit) and Apis honey (b) at the wavelength of (I) $290 \mathrm{~nm}$ and (II) $340 \mathrm{~nm}$. Phenolic acids: $\mathrm{A}=$ gallic acid, $\mathrm{B}=3$,4-dihydroxybenzoic acid, $\mathrm{C}=4$-hydroxybenzoic acid, $\mathrm{D}=$ chlorogenic acid, $\mathrm{E}=$ syringic acid, $\mathrm{F}=\mathrm{p}$-coumaric acid, $\mathrm{G}=$ ferulic acid, $\mathrm{H}=$ ellagic acid, $\mathrm{I}=$ benzoic acid, $\mathrm{J}=$ salicylic acid, and $\mathrm{K}=$ trans-cinnamic acid. Flavonoids: $\mathrm{L}=$ taxifolin, $\mathrm{M}=\mathrm{myricetin}$, $\mathrm{N}=$ quercetin, $\mathrm{O}=$ naringenin, and $\mathrm{P}=$ chrysin. 
TABLE 4: The profile and concentration of phenolic compounds ( $\mu \mathrm{g} / 100 \mathrm{~g}$ honey) in Heterotrigona itama honey from different botanical origins (acacia, gelam, and starfruit) and Apis mellifera (acacia) honey.

\begin{tabular}{|c|c|c|c|c|}
\hline \multirow{3}{*}{ Phenolic compounds } & \multicolumn{3}{|c|}{ Botanical origin of honey } & \multirow{3}{*}{$\begin{array}{c}\text { Apis mellifera } \\
\text { Acacia }\end{array}$} \\
\hline & \multicolumn{3}{|c|}{ Heterotrigona itama } & \\
\hline & Acacia & Gelam & Starfruit & \\
\hline \multicolumn{5}{|l|}{ Phenolic acids } \\
\hline Ferulic acid & $135.01 \pm 8.73^{\mathrm{a}}$ & $125.69 \pm 3.35^{\mathrm{a}}$ & $116.54 \pm 1.36^{\mathrm{a}}$ & $43.18 \pm 1.47^{\mathrm{b}}$ \\
\hline p-Coumaric acid & $87.54 \pm 10.37^{\mathrm{a}}$ & $84.83 \pm 0.89^{\mathrm{a}}$ & $59.67 \pm 0.02^{\mathrm{b}}$ & $33.70 \pm 0.81^{\mathrm{c}}$ \\
\hline trans-Cinnamic acid & ND & $6.60 \pm 0.40^{\mathrm{a}}$ & $19.37 \pm 0.40^{\mathrm{a}}$ & ND \\
\hline Salicylic acid & $137.72 \pm 5.77^{\mathrm{b}}$ & $113.00 \pm 1.35^{\mathrm{c}}$ & $302.38 \pm 1.10^{\mathrm{a}}$ & $71.04 \pm 1.20^{\mathrm{d}}$ \\
\hline Gallic acid & $34.04 \pm 0.42^{\mathrm{b}}$ & $145.02 \pm 3.52^{\mathrm{a}}$ & $32.76 \pm 0.02^{\mathrm{b}}$ & $34.27 \pm 0.01^{\mathrm{b}}$ \\
\hline Ellagic acid & $312.89 \pm 13.87^{\mathrm{b}}$ & $855.30 \pm 16.80^{\mathrm{a}}$ & $334.77 \pm 11.92^{\mathrm{b}}$ & $73.25 \pm 0.06^{\mathrm{c}}$ \\
\hline 3,4-Dihydroxy benzoic acid & $2.32 \pm 2.86^{\mathrm{c}}$ & $24.84 \pm 1.71^{\mathrm{b}}$ & $132.81 \pm 0.47^{\mathrm{a}}$ & ND \\
\hline Benzoic acid & $2,434.80 \pm 24.80^{c}$ & $2,808.40 \pm 65.20^{\mathrm{b}}$ & $12,626.00 \pm 14.70^{\mathrm{a}}$ & $738.08 \pm 1.58^{\mathrm{d}}$ \\
\hline 4-Hydroxy benzoic acid & $42.59 \pm 1.12^{\mathrm{b}}$ & $34.17 \pm 5.40^{\mathrm{b}}$ & $419.03 \pm 0.89^{\mathrm{a}}$ & ND \\
\hline Chlorogenic acid & $17.63 \pm 0.21^{\mathrm{c}}$ & $116.41 \pm 0.18^{\mathrm{b}}$ & $132.14 \pm 0.28^{\mathrm{a}}$ & $13.10 \pm 0.58^{\mathrm{d}}$ \\
\hline Syringic acid & $161.94 \pm 3.17^{\mathrm{c}}$ & $233.63 \pm 5.40^{\mathrm{b}}$ & $405.43 \pm 0.41^{\mathrm{a}}$ & $71.17 \pm 4.07^{\mathrm{d}}$ \\
\hline \multicolumn{5}{|l|}{ Flavonoids } \\
\hline Taxifolin & $248.69 \pm 3.15^{\mathrm{c}}$ & $496.33 \pm 4.00^{\mathrm{b}}$ & $1,212.70 \pm 3.07^{\mathrm{a}}$ & $76.50 \pm 1.63^{\mathrm{d}}$ \\
\hline Myricetin & $11.16 \pm 0.09^{\mathrm{d}}$ & $45.42 \pm 2.47^{\mathrm{a}}$ & $29.61 \pm 0.01^{\mathrm{b}}$ & $18.32 \pm 0.13^{\mathrm{c}}$ \\
\hline Quercetin & $11.66 \pm 0.01^{\mathrm{c}}$ & $15.31 \pm 0.36^{\mathrm{b}}$ & $29.82 \pm 0.08^{\mathrm{c}}$ & $11.66 \pm 0.04^{c}$ \\
\hline Naringenin & $14.69 \pm 0.73^{\mathrm{a}}$ & ND & $15.89 \pm 0.24^{\mathrm{a}}$ & ND \\
\hline Chrysin & $6.62 \pm 0.04^{\mathrm{d}}$ & $12.31 \pm 0.10^{\mathrm{c}}$ & $21.23 \pm 0.01^{\mathrm{b}}$ & $66.00 \pm 1.45^{\mathrm{a}}$ \\
\hline
\end{tabular}

${ }^{*}$ Data are expressed as mean \pm standard deviation. The letters in the same row $(\mathrm{a}-\mathrm{d})$ indicate significant differences at the level of $p<0.05$ between honey from different botanical origins. $\mathrm{ND}=$ not detected.

protocatechuic acid, epicatechin, and rutin) in H. itama honey collected from Johor, Malaysia. Biluca et al. [13] demonstrated the presence of mandelic acid, rosmarinic acid, caffeic acid, aromadendrin, vanillin, isoquercetin, umbelliferone, eriodictyol, sinapaldehyde, syringaldehyde, and carnosol in Brazilian stingless bee honey from different geographical origins. In a different study, Alvarez-Suarez et al. [12] found dihydrocaffeic acid, C-pentosyl-C-hexosylapigenin, quercetin deoxyhexosyl hexoside, apigenin trihexoside, kaempferol deoxyhexosyl hexoside, isohamnetin deoxyhexosyl hexoside, isohamnetin, bis-methylated quercetin, apigenin, kaempferol, methyl luteolin, and methyl quercetin in $M$. beecheii from Cuba. All these compounds were not detected in this present study, which could be explained by the difference in the origin of the honey, the bee species, and the method of analysis used.

Benzoic acid was the most abundant phenolic compound found in all honey samples with values ranging between $738.08 \mu \mathrm{g} / 100 \mathrm{~g}$ honey-12,626.00 $\mu \mathrm{g} / 100 \mathrm{~g}$ honey. Starfruit honey had the highest benzoic acid $(12,626.00 \mu \mathrm{g} / 100 \mathrm{~g}$ honey), followed by gelam $(2,808.40 \mu \mathrm{g} / 100 \mathrm{~g}$ honey), acacia $(2,434.80 \mu \mathrm{g} / 100 \mathrm{~g}$ honey), and Apis $(738.08 \mu \mathrm{g} / 100 \mathrm{~g}$ honey) honey. Statistical differences were observed between all honey samples. In a recent study, Braghini et al. [45] reported that carnosol was identified as the major phenolic compound in Melipona bicolor honey. In previous studies, fraxin was found abundantly in Ecuadorian stingless bee honey [46] and taxifolin in Melipona (Michmelia) seminigra merrillae honey from Brazil [13]. Regarding the flavonoids content, taxifolin was identified as the major flavonoid $(76.50-1,212.70 \mu \mathrm{g} / 100 \mathrm{~g}$ honey) in all honey samples investigated. However, stingless bee honey $(248.69-1,212.70 \mu \mathrm{g} / 100 \mathrm{~g}$ honey) exhibited significantly higher taxifolin content than Apis honey $(76.50 \mu \mathrm{g} / 100 \mathrm{~g}$ honey). Our result was in accordance with those previously found in Amazon honey from M. (Michmelia) seminigra merrillae [14]. On the other hand, luteolin was found as the predominant flavonoid in Melipona asilvai and Melipona quadrifascita honey; kaempferol in Melipona anthidioides, Melipona scutellaris, and M. subnitida honey; and apigenin in Melipona mandacaia honey from Sergipe state, Brazil [32]. Different types and concentrations of phenolic compounds in honey were reported from different studies, which might be attributed to the different botanical origins, bee species, and geographical locations of honey.

In this present study, ferulic acid, salicylic acid, ellagic acid, benzoic acid, 4-hydroxybenzoic acid, taxifolin, myricetin, quercetin, and naringenin were detected in stingless bee honey. To the best of our knowledge, this is the first report of the presence of these compounds in Malaysian stingless bee honey. The findings revealed that stingless bee honey contains a wide range of phenolic compounds. This finding could have a significant impact on the stingless bee industry sustainability as well as promote Malaysian stingless bee honey globally.

Overall, stingless bee honey exhibited more types and higher concentrations of phenolic compounds compared to Apis honey. This suggests that stingless bee honey is a good source of natural phenolic acids and flavonoids. These findings are consistent with those reported by AlvarezSuarez et al. [12] and Guerrini et al. [46]. Phenolic acids and flavonoids have been proven to have antioxidant activity, which has a significant correlation with honey's medicinal properties, and each of them has specific health benefits [47]. Furthermore, stingless bee honey has the potential in treating eye illnesses, wounds, cancer, diabetes mellitus, 


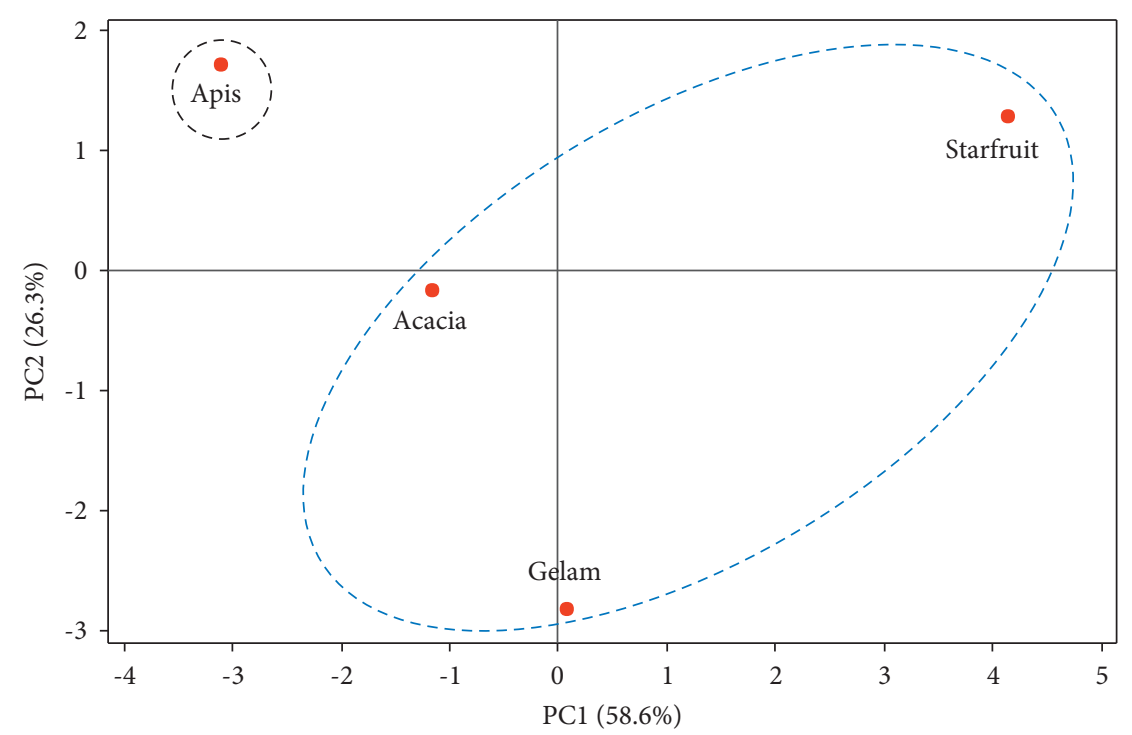

FIgURE 3: Score plot of stingless bee and Apis honey.

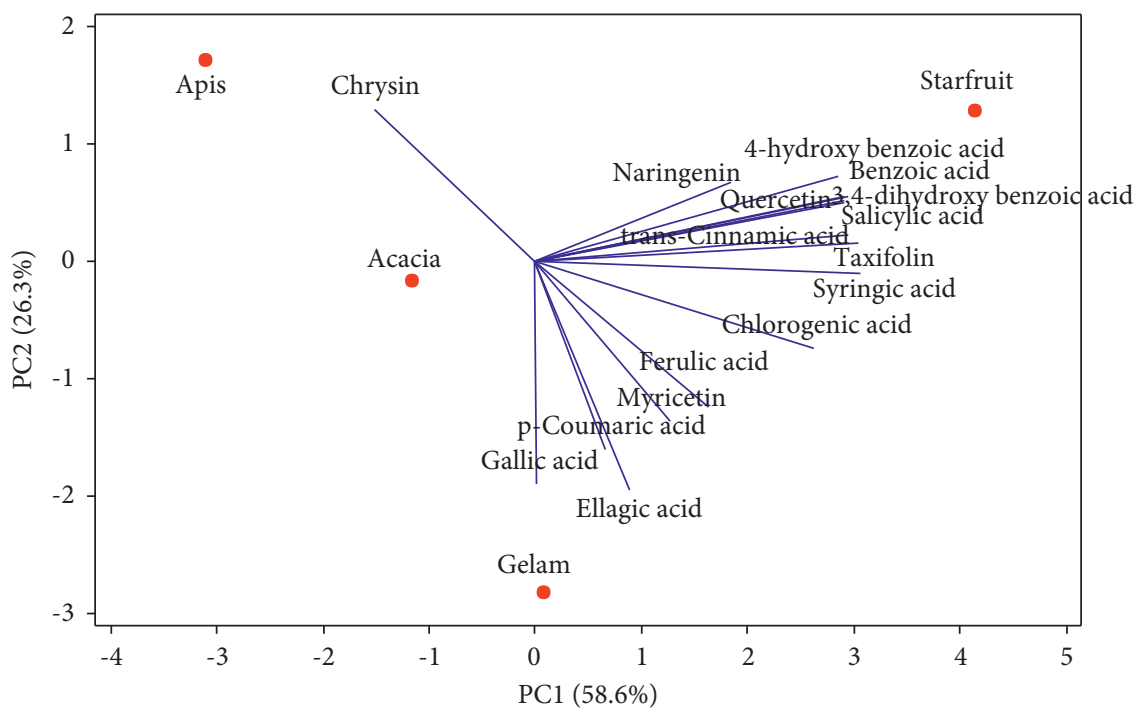

FIgURE 4: Biplot of phenolic compounds in stingless bee and Apis honey.

hypertension, microbial infection, fertility problems, and dysregulated lipid profiles [47]. This indicates that stingless bee has a great potential to be commercialized and consumed by a large population. Acacia, gelam, and starfruit honey can be a good choice as an antioxidant source for humans. Since they have high antioxidant content than Apis honey, we believe that stingless bee honey has a better effect on human health.

3.5. Multivariate Analysis. Multivariate analysis was performed to determine potential phenolic compounds, which can be used as a chemical marker to distinguish stingless bee honey from Apis honey. The principal component analysis (PCA) was used to identify honey based on the concentration of phenolic compounds. To establish the best parameters for classifying honey samples, two principal components with eigenvalues greater than one were extracted. The first principal component (PC1) accounted for $58.6 \%$ of the variance, while the second principal component (PC2) accounted for $26.3 \%$. These two components explained $84.9 \%$ of the variation in the data. Based on the score plot (Figure 3), all honey samples were scattered away from each other, indicating that all honey samples contained different types and concentrations of phenolic compounds. From the score plot, Apis honey was located far away from the stingless bee honey, proving that Apis honey was significantly different from the stingless bee honey in terms of the phenolic compounds. This finding suggests that phenolic compounds can distinguish Apis honey from stingless bee honey. A biplot was further created to display the relationship between honey samples and phenolic compounds (Figure 4). Then, a loading plot was performed to assess which phenolic compounds contributed significantly to 


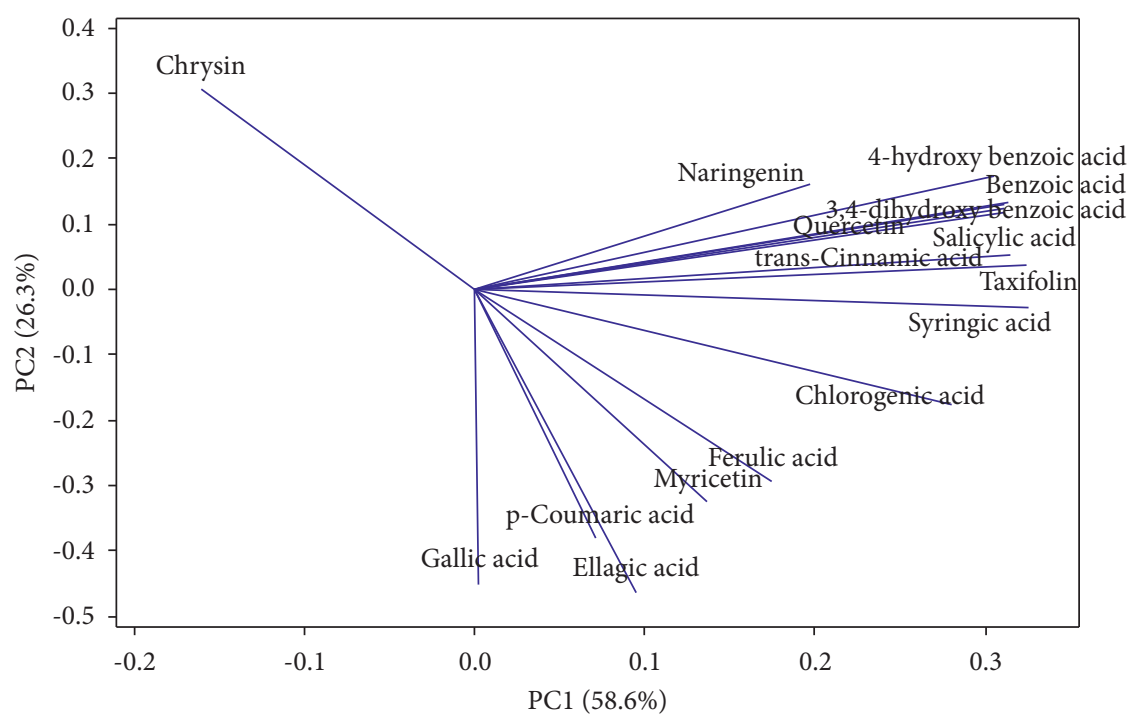

FIgURE 5: Loading plot of phenolic compounds in stingless bee and Apis honey.

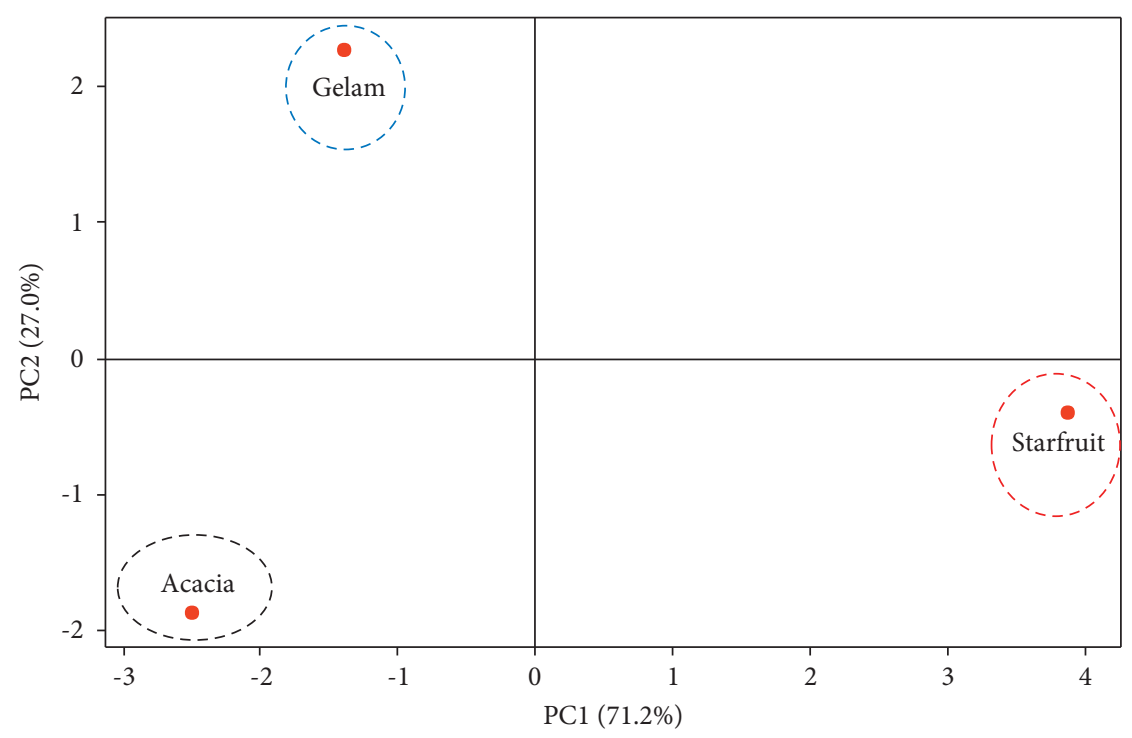

FIGURE 6: Score plot of stingless bee honey (acacia, gelam, and starfruit).

the separation (Figure 5). According to the PC2, chrysin was the only phenolic compound responsible to separate Apis honey from stingless bee honey. As a result, chrysin can be used as a chemical marker to distinguish Apis honey from stingless bee honey.

To study the potential to differentiate acacia, gelam, and starfruit honey, data of Apis honey were removed, and principal component analysis (PCA) was constructed. The first principal component (PC1) accounted for $71.2 \%$ of the variance, while the second principal component (PC2) accounted for $27.0 \%$. These two components explained $98.2 \%$ of the variation in the data. Based on the score plot (Figure 6), all stingless bee honey were well separated, indicating that all honey samples were significantly different in phenolic compounds content.

The most influential phenolic compounds responsible for clustering to be identified as a potential marker for all honey samples were determined using biplot (Figure 7(a)) and loading plot (Figure 7(b)). Based on the loading plot, gallic acid and ellagic acid have a strong impact on the 


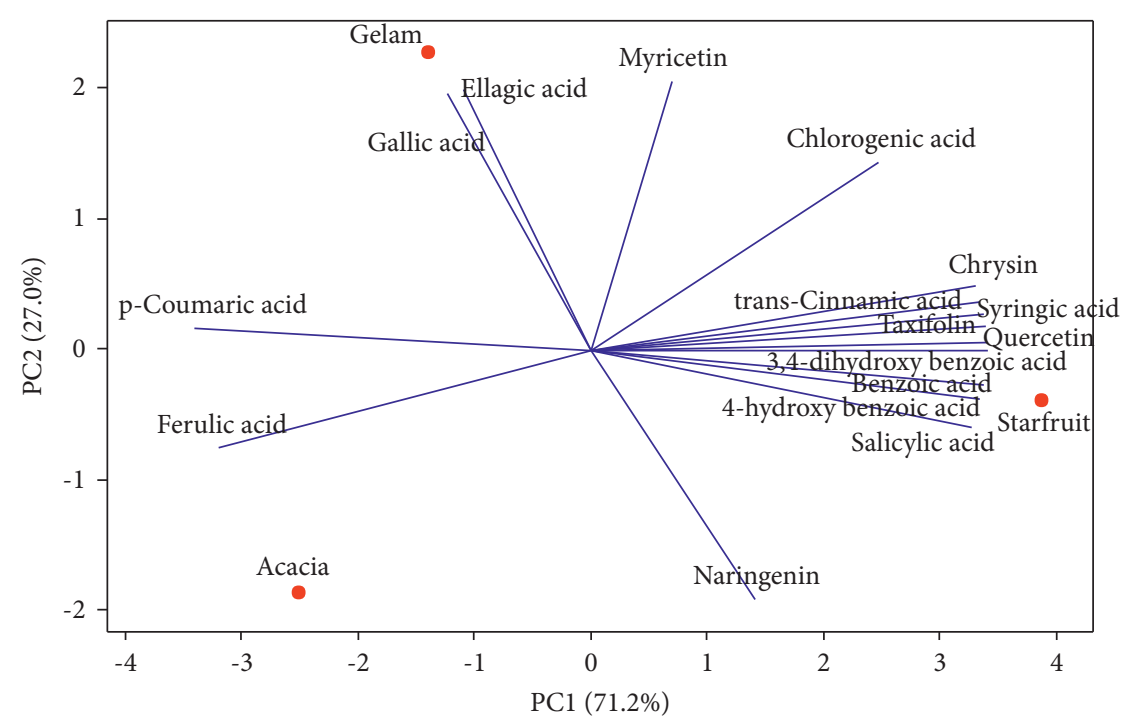

(a)

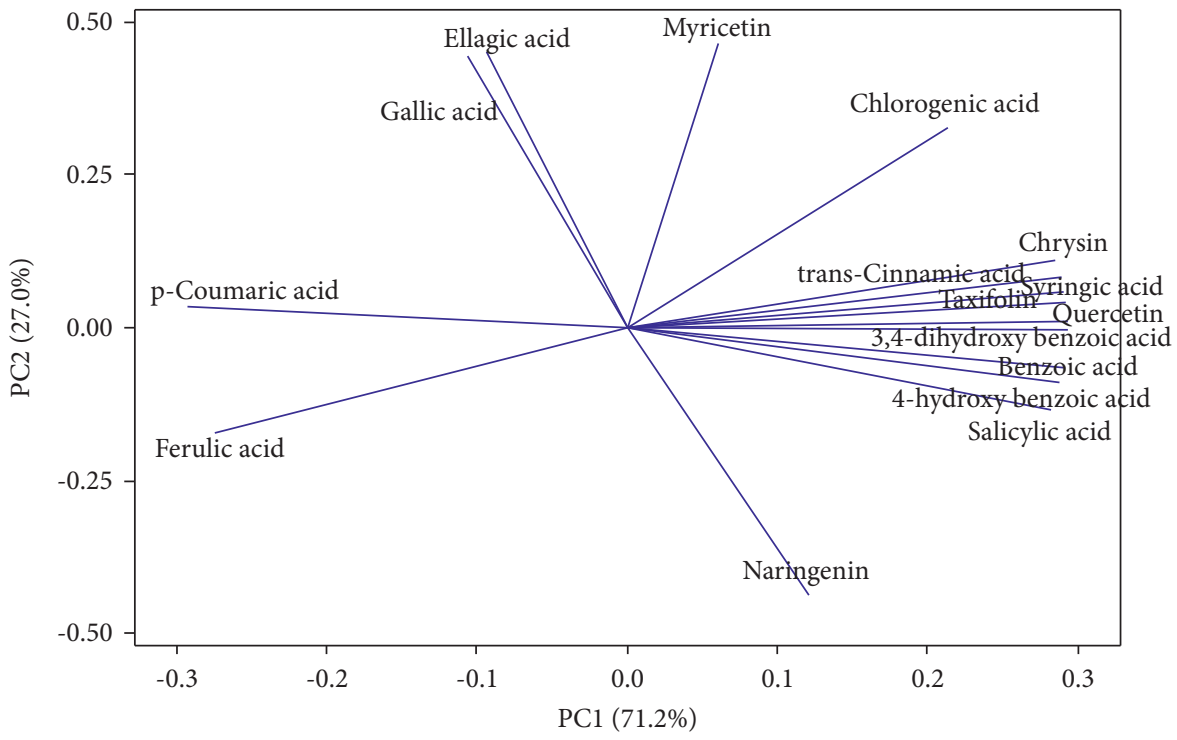

(b)

Figure 7: Biplot (a) and loading plot (b) of acacia, gelam, and starfruit honey.

separation of gelam honey. Salicylic acid, benzoic acid, and 4-hydroxybenzoic acid are responsible for the separation of starfruit honey, while ferulic acid is the only one that separated acacia from other honey samples.

\section{Conclusion}

This study discovered that botanical origin significantly influences antioxidant activity and the composition of phenolic compounds in honey. Flavonoids were shown to have a significant relationship with the antioxidant activity (FRAP) of honey. In addition, HPLC analysis indicated and validated that stingless bee honey is rich in phenolic components as compared to Apis honey, showing that stingless bee honey is a valuable source of natural phenolic acids and flavonoids. Furthermore, the findings suggest that the botanical origin has a significant impact on the content of phenolic compounds in honey. A multivariate data analysis was used to find a potential marker that might be used to distinguish honey samples based on their phenolic compounds. The results showed that chrysin successfully distinguished the stingless bee honey from Apis honey. Gelam honey was discriminated by gallic acid and ellagic acid, starfruit honey by salicylic acid, benzoic acid, and 4-hydroxybenzoic acid, while acacia honey by ferulic acid. However, the number of samples used in this study was limited. Thus, a further investigation with a large number of samples is required in order to confirm the present results.

\section{Data Availability}

Data used to support the findings of this study are included in the article. 


\section{Conflicts of Interest}

The authors declare that there are no potential conflicts of interest.

\section{Acknowledgments}

The authors like to thank the Ministry of Higher Education (MOHE) for the research support (FRGS/1/2020/STG04/ $\mathrm{UPM} / 01 / 1)$ and the HICoE awarded to the Institute of Tropical Agriculture and Food Security (ITAFoS), Universiti Putra Malaysia. The authors would also like to thank ITAFoS and the Faculty of Food Science and Technology for the research facilities rendered.

\section{References}

[1] S. Z. Hussein, K. M. Yusoff, S. Makpol, and Y. A. M. Yusof, "Antioxidant capacities and total phenolic contents increase with gamma irradiation in two types of Malaysian honey," Molecules, vol. 16, no. 8, pp. 6378-6395, 2011.

[2] A. Michalkiewicz, M. Biesaga, and K. Pyrzynska, "Solid-phase extraction procedure for determination of phenolic acids and some flavonols in honey," Journal of Chromatography A, vol. 1187, no. 1-2, pp. 18-24, 2008.

[3] D. Arráez-Román, A. M. Gómez-Caravaca, M. GómezRomero, A. Segura-Carretero, and A. Fernández-Gutiérrez, "Identification of phenolic compounds in rosemary honey using solid-phase extraction by capillary electrophoresis-electrospray ionization-mass spectrometry," Journal of Pharmaceutical and Biomedical Analysis, vol. 41, no. 5, pp. 1648-1656, 2006.

[4] M. Moniruzzaman, C. Yung An, P. V. Rao et al., "Identification of phenolic acids and flavonoids in monofloral honey from Bangladesh by high performance liquid chromatography: determination of antioxidant capacity," BioMed Research International, vol. 2014, Article ID 737490, 11 pages, 2014.

[5] O. O. Erejuwa, S. A. Sulaiman, and M. S. Ab Wahab, "Honey: a novel antioxidant," Molecules, vol. 17, no. 4, pp. 4400-4423, 2012.

[6] V. Kaškonienè and P. R. Venskutonis, "Floral markers in honey of various botanical and geographic origins: a review," Comprehensive Reviews in Food Science and Food Safety, vol. 9, no. 6, pp. 620-634, 2010.

[7] I. Jasicka-Misiak, A. Poliwoda, M. Dereń, and P. Kafarski, "Phenolic compounds and abscisic acid as potential markers for the floral origin of two Polish unifloral honeys," Food Chemistry, vol. 131, no. 4, pp. 1149-1156, 2012.

[8] F. A. Tomás-Barberán, I. Martos, F. Ferreres, B. S. Radovic, and E. Anklam, "HPLC flavonoid profiles as markers for the botanical origin of European unifloral honeys," Journal of the Science of Food and Agriculture, vol. 81, no. 5, pp. 485-496, 2001.

[9] K. Pyrzynska and B. Magdalena, "Analysis of phenolic acids and flavonoids in honey," TRAC Trends in Analytical Chemistry, vol. 28, no. 7, pp. 893-902, 2009.

[10] S. Z. A. Makawi, E. A. Gadkariem, and S. M. H. Ayoub, "Determination of antioxidant flavonoids in Sudanese honey samples by solid phase extraction and high-performance liquid chromatography," Journal of Chemistry, vol. 6, Article ID 382504, 2009.

[11] A. Pascual-Maté, S. M. Osés, M. A. Fernández-Muiño, and M. T. Sancho, "Analysis of polyphenols in honey: extraction, separation, and quantification procedures," Separation \& Purification Reviews, vol. 47, no. 2, pp. 142-158, 2018.

[12] J. M. Alvarez-Suarez, F. Giampieri, A. Brenciani et al., "Apis mellifera vs. Melipona beecheii Cuban polifloral honeys: a comparison based on their physicochemical parameters, chemical composition and biological properties," Lebensmittel-Wissenschaft \& Technologie, vol. 87, pp. 272-279, 2018.

[13] F. C. Biluca, J. S. De Gois, M. Schulz et al., "Phenolic compounds, antioxidant capacity and bioaccessibility of minerals of stingless bee honey (Meliponinae)," Journal of Food Composition and Analysis, vol. 63, pp. 89-97, 2017.

[14] I. A. A. da Silva, T. M. S. da Silva, C. A. Camara et al., "Phenolic profile, antioxidant activity and palynological analysis of stingless bee honey from Amazonas, Northern Brazil," Food Chemistry, vol. 141, no. 4, pp. 3552-3558, 2013.

[15] J. M. Sousa, E. L. De Souza, G. Marques et al., "Polyphenolic profile and antioxidant and antibacterial activities of monofloral honeys produced by Meliponini in the Brazilian semiarid region," Food Research International, vol. 84, pp. 61-68, 2016.

[16] P. S. Oliveira, R. C. S. Müller, K. D. G. F. Dantas, C. N. Alves, M. A. M. De Vasconselos, and G. C. Venturian, "Phenolic acids, flavonoids and antioxidant activity in honey of melipona fasciculata, M. flavolineata (Apidae, Meliponini) and Apis mellifera (Apidae, Apini) from the Amazon," Química Nova, vol. 35, no. 9, pp. 1728-1732, 2012.

[17] Y. Ranneh, F. Ali, M. Zarei, A. M. Akim, H. A. Hamid, and H. Khazaai, "Malaysian stingless bee and Tualang honeys: a comparative characterization of total antioxidant capacity and phenolic profile using liquid chromatography-mass spectrometry," Lebensmittel-Wissenschaft \& Technologie, vol. 89, pp. 1-9, 2018.

[18] M. Majid, M. S. Ellulu, and M. F. Abu Bakar, "Melissopalynological study, phenolic compounds, and antioxidant properties of heterotrigona itama honey from Johor, Malaysia," Scientifica, vol. 2020, Article ID 2529592, 9 pages, 2020.

[19] S. Z. Garjanovic, J. M. Alvarez-Suarez, M. M. Novakovic, and F. T. Pastor, "Comparative analysis of antioxidant activity of honey of different floral sources using recently developed polarographic and various spectrophotometric assays," Journal of Food Composition and Analysis, vol. 30, pp. 13-18, 2013.

[20] R. Kamboj, M. B. Bera, and V. Nanda, "Evaluation of physicochemical properties, trace metal content and antioxidant activity of Indian honeys," International Journal of Food Science and Technology, vol. 48, pp. 578-587, 2013.

[21] A. Meda, C. E. Lamien, M. Romito, J. Millogo, and O. G. Nacoulma, "Determination of the total phenolic, flavonlid, and proline contents in Burkina Fasan honey, as well as their radical scavenging activity," Food Chemistry, vol. 91, pp. 571-577, 2005.

[22] M. I. Khalil, N. Alam, M. Moniruzzaman, S. A. Sulaiman, and S. H. Gan, "Phenolic acid composition and antioxidant properties of Malaysian honeys," Journal of Food Science, vol. 76, no. 6, pp. C921-C928, 2011.

[23] M. Kassim, M. Achoui, M. R. Mustafa, M. A. Mohd, and K. M. Yusoff, "Ellagic acid, phenolic acids, and flavonoids in Malaysian honey extracts demonstrate in vitro anti-inflammatory activity," Nutrition Research, vol. 30, no. 9, pp. $650-659,2010$.

[24] I. C. F. R. Ferreira, E. Aires, J. C. M. Barreira, and L. M. Estevinho, "Antioxidant activity of Portuguese honey 
samples: different contributions of the entire honey and phenolic extract," Food Chemistry, vol. 114, no. 4, pp. 1438-1443, 2009.

[25] M. F. Abu Bakar, S. B. Sanusi, F. I. Abu Bakar, J. C. Ong, and Z. Mian, "Physicochemical and antioxidant potential of raw unprocessed honey from Malaysian stingless bees," Pakistan Journal of Nutrition, vol. 16, no. 11, pp. 888-894, 2017.

[26] S. Z. Imtiazah, H. Zaharah, I. Murni, F. Tufail Ahmad, and H. M. Yusof, "Honeybee honey and stingless bee honey quality characteristics and their anti-cancer potential in HeLa cells," Food Research, vol. 5, no. 3, pp. 413-422, 2019.

[27] F. T. Ahmad, M. N. Lani, S. A. Nazari et al., "Antioxidant and antimicrobial properties of honey, propolis and bee bread of stingless bee (Geniotrigona thoracica)," Asian Journal of Agriculture and Biology, vol. 7, pp. 76-85, 2019.

[28] N. I. Ismail, M. R. A. Kadir, R. M. Zulkifli, and M. Mohamed, "Comparison of physicochemical, total protein and antioxidant profiles between Malaysian Apis and Trigona honeys," Malaysian Journal of Analytical Sciences, vol. 25, no. 2, pp. 243-256, 2021.

[29] T. M. S. Silva, F. P. dos Santos, A. Evangelista-Rodrigues et al., "Phenolic compounds, melissopalynological, physicochemical analysis and antioxidant activity of jandaíra (Melipona subnitida) honey," Journal of Food Composition and Analysis, vol. 29, no. 1, pp. 10-18, 2013.

[30] K. Selvaraju, P. Vikram, J. M. Soon, K. T. Krishnan, and A. Mohammed, "Melissopalynological, physicochemical and antioxidant properties of honey from West Coast of Malaysia," Journal of Food Science and Technology, vol. 56, no. 5, pp. 2508-2521, 2019.

[31] A. W. F. Duarte, M. R. dos Santos Vasconcelos, A. P. D. de Menezes, S. C. da Silva, M. Oda-Souza, and A. M. Q. Lopez, "Composition and antioxidant activity of honey from Africanized and stingless bees in Alagoas (Brazil): a multivariate analysis," Journal of Apicultural Research, vol. 51, no. 1, pp. 23-35, 2012.

[32] R. G. D. Oliveira, S. Jain, A. C. Luna, L. D. S. Freitas, and E. D. D. Araújo, "Screening for quality indicators and phenolic compounds of biotechnological interest in honey samples from six species of stingless bees (Hymenoptera: apidae)," Food Science and Technology, vol. 37, no. 4, pp. 552-557, 2017.

[33] M. H. Muruke, "Assessment of antioxidant properties of honeys from Tanzania," Journal of Biology, Agriculture and Healthcare, vol. 4, no. 27, pp. 22-32, 2014.

[34] S. Ávila, M. R. Beux, R. H. Ribani, and R. C. Zambiazi, "Stingless bee honey: quality parameters, bioactive compounds, health-promotion properties and modification detection strategies," Trends in Food Science \& Technology, vol. 81, pp. 37-50, 2018.

[35] L. S. Chua, N. L. A. Rahaman, N. A. Adnan, and T. T. Eddie Tan, "Antioxidant activity of three honey samples in relation with their biochemical components," Journal of Analytical Methods in Chemistry, vol. 2013, Article ID 313798, 8 pages, 2013.

[36] A. M. Aljadi and M. Y. Kamaruddin, "Evaluation of the phenolic contents and antioxidant capacities of two Malaysian floral honeys," Food Chemistry, vol. 85, no. 4, pp. 513-518, 2004.

[37] S. P. Kek, N. L. Chin, Y. A. Yusof, S. W. Tan, and L. S. Chua, "Classification of entomological origin of honey based on its physicochemical and antioxidant properties," International Journal of Food Properties, vol. 20, no. sup3, pp. S2723-S2738, 2017.
[38] B. K. Chan, H. Haron, R. A. Talib, and P. Subramaniam, "Physical properties, antioxidant content and anti-oxidative activities of Malaysian stingless kelulut (Trigona spp.) Honey," Journal of Agricultural Science, vol. 9, no. 13, pp. 32-40, 2017.

[39] J. A. Nweze, J. I. Okafor, E. I. Nweze, and J. E. Nweze, "Evaluation of physicochemical and antioxidant properties of two stingless bee honeys: a comparison with Apis mellifera honey from Nsukka, Nigeria," BMC Research Notes, vol. 10, 2017.

[40] M. Moniruzzaman, S. A. Sulaiman, M. I. Khalil, and S. H. Gan, "Evaluation of physicochemical and antioxidant properties of sourwood and other Malaysian honeys: a comparison with manuka honey," Chemistry Central Journal, vol. 7, 2013.

[41] S. Maurya, A. K. Kushwaha, S. Singh, and G. Singh, "An overview on antioxidative potential of honey from different flora and geographical origins," Indian Journal of Natural Products and Resources, vol. 5, pp. 9-19, 2014.

[42] J. Lachman, A. Hejtmankova, J. Sýkora, J. Karban, M. Orsak, and B. Rygerova, "Contents of major phenolic and flavonoid antioxidants in selected Czech honey," Czech Journal of Food Sciences, vol. 28, no. 5, pp. 412-426, 2010.

[43] M. Ahmed, M. Imtiaz Shafiq, A. Khaleeq et al., "Physiochemical, biochemical, minerals content analysis, and antioxidant potential of national and international honeys in Pakistan,"Journal of Chemistry, vol. 2016, Article ID 8072305 , 10 pages, 2016.

[44] M. I. Khalil, M. Mahaneem, S. M. S. Jamalullail, N. Alam, and S. A. Sulaiman, "Evaluation of radical scavenging activity and colour intensity of nine Malaysian honeys of different origin," Journal of ApiProduct and ApiMedical Science, vol. 3, no. 1, pp. 04-11, 2011.

[45] F. Braghini, F. C. Biluca, L. V. Gonzaga et al., "Impact of shortterm thermal treatment on stingless bee honey (Meliponinae): quality, phenolic compounds and antioxidant capacity," Journal of Food Processing and Preservation, vol. 43, no. 7, Article ID e13954, 2019.

[46] A. Guerrini, R. Bruni, S. Maietti et al., "Ecuadorian stingless bee (Meliponinae) honey: a chemical and functional profile of an ancient health product," Food Chemistry, vol. 114, no. 4, pp. 1413-1420, 2009.

[47] F. A. Zulkhairi Amin, S. Sabri, S. M. Mohammad et al., "Therapeutic properties of stingless bee honey in comparison with European bee honey," Advances in Pharmacological Sciences, vol. 2018, Article ID 6179596, 12 pages, 2018. 